\title{
A preliminary estimation of tissue factor pathway inhibitor (TFPI) and protein C in patients with intracranial tumors
}

\author{
Danuta Rość ${ }^{1, A, C-E}$, Ewa Grabarczyk ${ }^{1, A, B}$, Maciej Bierwagen ${ }^{2, A, B}$, Marcin Wierciński², A, B, \\ Krzysztof Góralczyk ${ }^{1, C}$, Beata Haor ${ }^{1, C}$, Barbara Ruszkowska-Ciastek ${ }^{1}$, C, E,F \\ 1 Department of Pathophysiology, Faculty of Pharmacy, Nicolaus Copernicus University in Toruń, Collegium Medicum in Bydgoszcz, Poland \\ ${ }^{2}$ Neurosurgery and Traumatology Ward, University Hospital No. 2 in Bydgoszcz, Poland \\ A - research concept and design; $\mathrm{B}$ - collection and/or assembly of data; $\mathrm{C}$ - data analysis and interpretation; \\ $\mathrm{D}$ - writing the article; $\mathrm{E}$ - critical revision of the article; $\mathrm{F}$ - final approval of the article
}

Address for correspondence

Barbara Ruszkowska-Ciastek

E-mail: ruszkowska.basia@gmail.com

Funding sources

None declared

Conflict of interest

None declared

Received on January 13, 2016

Reviewed on November 16, 2016

Accepted December 15, 2016

\begin{abstract}
Background. In patients with intracranial tumors, hypercoagulability is observed due to brain tissue and tumor cells being the source of tissue factor.

Objectives. The aim of the study was to assess tissue factor (TF), tissue factor pathway inhibitor (TFPI) and protein C in the plasma and tumor tissue homogenate in patients with intracranial tumors.

Material and methods. The study included 77 patients; 24 patients were diagnosed with glioma, 20 patients with meningioma and 33 patients with metastatic tumors; mean age -54 years. The material for the study was the plasma and tumor tissue homogenate sampled during surgery. The control group consisted of 30 controls; mean age - 51 years. In the plasma of all the participants and in tumor tissue homogenate, the concentrations of TF-Ag, TFPI-Ag and protein C activity, and the concentration of total protein were measured. The results were converted per $\mathrm{mg}$ of protein.

Results. In patients with intracranial tumors, elevated concentrations of TF-Ag, TFPI-Ag and protein C activity were noted, also after the conversion per mg of protein. A 100 -fold higher concentration of TF per $1 \mathrm{mg}$ of protein was found in tumor tissue compared to the patients' plasma. In tumor tissue homogenate, a lower TFPI concentration and a lower protein C activity were recorded.

Conclusions. The study confirmed the essential prothrombotic properties in patients with intracranial tumors, expressed with an elevated TF level, as well as a tremendous amount of TF in tumor tissue homogenate derived from tumors. The elevated concentration of TFPl and protein C activity converted per $\mathrm{mg}$ of total protein should be analyzed in terms of their pleiotropic function, along with the participation in hemostasis control. It seems that the reduced protein C activity and low TFPl level are associated with the enormous TF value in tumor tissue homogenates.
\end{abstract}

Key words: tissue factor, tissue factor pathway inhibitor, protein C, intracranial tumors

DOI

$10.17219 /$ acem $/ 67760$

Copyright

Copyright by Author(s)

This is an article distributed under the terms of the

Creative Commons Attribution Non-Commercial License

(http://creativecommons.org/licenses/by-nc-nd/4.0/) 


\section{Introduction}

Tissue factor is a glycoprotein located in the cell membrane of tunica media myocytes, and in the blood stream it is scarce. It acts as a cellular receptor, and its structure covers an extracellular part responsible for the creation of the complex with factor VII/VIIa activating coagulation, while the transmembrane part is responsible for stabilizing molecules, and the intracytoplasmatic part is involved in signal transmission. ${ }^{1}$ The interaction between tissue factor and factor VIIa leads to the formation of active complex TF/VIIa. The TF/VIIa complex is the main initiator of extrinsic coagulation, which plays a crucial role in thrombin generation, and it is directly associated with thrombosis and endothelial dysfunction. ${ }^{1,2}$

It is believed that in patients with gliomas, TF is the key cellular trigger of the coagulation process, however TF also plays an important role in signaling. It has been shown that it induces signaling via coagulation protease-activated receptors 1 (PAR-1/thrombin receptor) and 2 (PAR-2) and, consequently, it leads to overexpression of many genes involved in the proliferative, migratory, pro-inflammatory and angiogenic phenotypes of tumor cells. ${ }^{3}$

The natural coagulation inhibitors include tissue factor pathway inhibitor (TFPI), antithrombin, protein $\mathrm{C}$ and $\mathrm{S}$, as well as heparan sulfate. TFPI is the main inhibitor of TF-dependent coagulation activation. It is bound with factor Xa since in this combination it inhibits complex TF/ VIIa. It is the endothelium that is the main TFPI source; $85 \%$ is bound to the endothelial cell surface and $15 \%$ is present in the blood. Eighty-five percent of TFPI circulating in the blood is inactive and connected with lipoproteins, and $15 \%$ of TFPI occurs in an active form which rapidly inhibits TF/VIIa complex. ${ }^{1,4}$ It has been shown that TFPI infusion suppresses thrombosis, which has been induced in experimental animals by TF or endotoxin. On the other hand, tissue factor pathway inhibitor deficiency leads to the thrombotic process. ${ }^{4-6}$

Protein $\mathrm{C}(\mathrm{PC})$ is an important component of the inhibition system associated with endothelium. PC activation requires binding to 2 receptors present on the surface of endothelial cells; thrombomodulin and endothelial protein $\mathrm{C}$ receptor (EPCR). The connection of thrombin to thrombomodulin results in a loss of procoagulant thrombin properties and promotes protein $\mathrm{C}$ activation. This reaction is remarkably enhanced when protein $C$ connects to receptor EPCR. ${ }^{7,8}$ Active protein $\mathrm{C}$ mainly leads to the proteolytic distribution of coagulation cofactors; factors Va and VIIIa. Factor Va increases the formation of the prothrombinase complex 10,000-fold, while factor VIIIa is an essential cofactor for the activation of factor $\mathrm{X}$ to $\mathrm{Xa}$ in the tenase complex and it enhances this reaction 200,000-fold. Thus, the breakdown of factors Va and VIIIa by active protein $\mathrm{C}$ results in a significant reduction of thrombin formation and coagulation suppression. ${ }^{9}$
Studies of natural coagulation inhibitors in patients with intracranial tumors are rare, and the results are divergent. Recently, additional TFPI and protein $C$ properties have been discovered; namely their involvement in cell proliferation and migration, as well as their participation in extracellular matrix functioning. With all that in mind, the aim of the study was to assess tissue factor (TF), tissue factor pathway inhibitor (TFPI) and protein $C$ in the plasma and tumor tissue homogenate in patients with intracranial tumors.

\section{Material and methods}

The study group consisted of 77 patients with intracranial tumors (49 women and 28 men) aged from 26 to 73 years (mean age was 54 years). The patients received care in the Neurosurgery and Traumatology Ward of University Hospital No. 2 in Bydgoszcz, Poland. The patients underwent a surgical procedure to remove the tumor. Forty patients were over 60 , while 37 were below 60 . Neurological deficits were observed in 22 patients. The histological grade of tumor malignancy revealed in 34 patients was degree 1 and 2, and in 43 subjects it was degree 3 and 4. In 38 patients, a total tumor resection was made, and a subtotal resection in 39 patients. Fifty-one patients were hospitalized for less than 7 days and 26 subjects for longer in the Neurosurgery and Traumatology Ward. The control group consisted of 30 healthy volunteers (19 women and 11 men) aged 25-68 years (mean age was 51 years).

For the study, venous blood was collected from the patients before surgery and during surgery a tumor section $(1 \times 1 \times 1 \mathrm{~cm})$ was isolated, frozen and stored at $-86^{\circ} \mathrm{C}$ until assayed within 6 months. From the healthy controls, the venous blood was collected in a fasting state after $30 \mathrm{~min}$ of rest between 7:00 and 9:00 a.m., and after a 12 h overnight fast.

The blood samples were immediately mixed and centrifuged at $3000 \times \mathrm{g}$ at $+4^{\circ} \mathrm{C}$ for $15 \mathrm{~min}$, and then the citrated plasma was frozen at $-80^{\circ} \mathrm{C}$ (as specified by the manufacturer) until assayed within 6 months. The tumor tissue samples were homogenized with liquid nitrogen, and treated with buffer (TRIS + Triton) to obtain the extracts of tumor tissue homogenates to be centrifuged, and separated into Eppendorf tubes.

In the plasma and tumor tissue homogenates, the following parameters were determined:

1. the concentration of tissue factor antigen (TF-Ag), applying the Imubind TF ELISA method (Sekusui Diagnostics, Stamford, USA);

2. the concentration of tissue factor pathway inhibitor antigen (TFPI-Ag), using the Imubind TFPI ELISA technique (Sekusui Diagnostics, Stamford, USA);

3. the activity of protein $C$, with the Asserachrom Protein C ELISA technique (Diagnostica Stago S.A.S., Asnières sur Seine, France); and

4. the concentration of total protein. 
The study protocol was approved by the Bioethics Committee of Collegium Medicum in Bydgoszcz, Nicolaus Copernicus University in Toruń (KB/497/2012). All the participants gave their written informed consent.

\section{Statistical analysis}

The statistical analysis was performed with the use of STATISTICA v. 12.0 software (StatSoft ${ }^{\circledR}$, StatSoft, Inc., Tulsa, USA). The Shapiro-Wilk test was used to assess the normality of the distribution, which facilitated the use of Student's t-test for independent and dependent variables; mean (X) and standard deviations (SD) were determined for those variables. The U-Mann-Whitney ranksum test, the Kruskal-Wallis test for independent variables and the Wilcoxon test for dependent variables were used when the distribution was not normal. The parameters with values deviating from a normal distribution were described by the median (Me), lower quartile (Q1) and upper quartile (Q3). Also, the analysis of variance was applied. The $\mathrm{p}$-values $<0.05$ were considered significant.

\section{Results}

Table 1 shows significantly higher TF-Ag levels in the plasma of patients with intracranial tumors than in the control group ( $p=0.0001)$. The analysis of TF-Ag concentration per mg of total protein in both groups demonstrates significantly higher TF levels in the patients than in the healthy controls $(\mathrm{p}<0.0001)$. Also, TFPI-Ag

Table 1. Concentrations of TF-Ag and TFPI-Ag and protein C activity in the plasma of patients with intracranial tumors and controls, also converted per mg of protein

\begin{tabular}{|l|c|c|c|c|}
\hline Parameters & Statistics & $\begin{array}{c}\text { Study group } \\
n=77\end{array}$ & $\begin{array}{c}\text { Control } \\
\text { group } \\
n=30\end{array}$ & p-values \\
\hline TF-Ag & Q1 & 168.59 & 117.39 & \\
(ng/mL) & Me & 263.84 & 164.28 & $<0.0001^{*}$ \\
plasma & Q3 & 501.22 & 183.85 & \\
\hline TF-Ag & Q1 & 2.68 & 1.60 & \\
(ng/mg P) & Me & 4.60 & 2.35 & $<0.0001^{*}$ \\
plasma & Q3 & 7.59 & 3.01 & \\
\hline TFPl-Ag & Q1 & 75.56 & 68.96 & \\
(ng/mL) & Me & 95.44 & 83.33 & 0.0999 \\
plasma & Q3 & 134.00 & 94.78 & \\
\hline TFPI-Ag & Q1 & 1.15 & 1.07 & \\
(ng/mg P) & Me & 1.49 & 1.21 & $0.0218^{*}$ \\
plasma & Q3 & 2.29 & 1.52 & \\
\hline Protein C & M & 120.21 & 113.48 & $0.0331^{*}$ \\
(\%) & SD & 9.92 & 12.93 & \\
\hline Plasma & SD & & 1.71 & $<0.0001^{*}$ \\
\hline Protein C & M & 2.37 & 0.29 & \\
(\%/mg P) & SD & 0.34 & & \\
\hline Plasma & & & & \\
\hline & & & & \\
\hline & & & & \\
\hline
\end{tabular}

* - significant. level in the study group expressed per mg of protein demonstrated significantly higher values than in the control group ( $\mathrm{p}<0.0218$ ). Protein $\mathrm{C}$ activity in the plasma and as converted per $\mathrm{mg}$ of protein were significantly higher in the patients than in the healthy individuals ( $\mathrm{p}=0.0331 ; \mathrm{p}<0.0001$, respectively).

Among the 77 patients with intracranial tumors, the histopathological examination demonstrated the occurrence of gliomas in 24 patients, meningiomas in 20 patients and metastatic tumors in 33 patients. The comparison of the TF-Ag and TFPI-Ag concentrations and the activity of protein $\mathrm{C}$ in the plasma and in tumor tissue homogenates did not show any significant tumor-specific differences. Neither did the conversion per mg of protein of TF-Ag and TFPI-Ag demonstrate any significant differences between patients with gliomas, meningiomas and tumors metastatic to the brain. However, the highest TF concentration in tumor tissue homogenates was observed in patients with meningioma. The comparison of the TF concentration in the plasma of the subjects, expressed per mg of protein, with the TF concentration in tumor tissue homogenates presented that, in the case of meningiomas, the TF concentration was 157-fold higher in tumor tissue homogenate than in the plasma

Fig. 1. TFPI-Ag concentration in the plasma and tumour tissue homogenate in patients with intracranial tumours converted per $1 \mathrm{mg}$ of protein

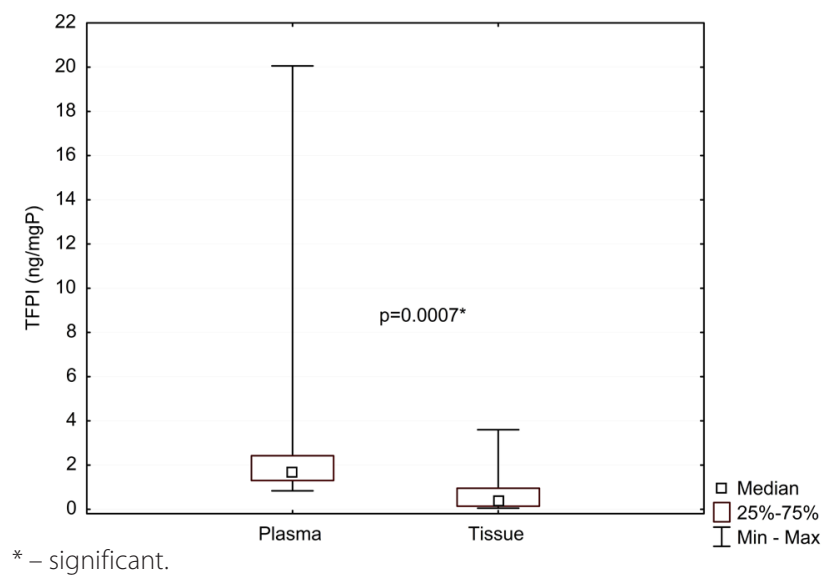

Fig. 2. Activity of protein C converted per $1 \mathrm{mg}$ of protein in the plasma and tumour tissue homogenates in patients with intracranial tumours

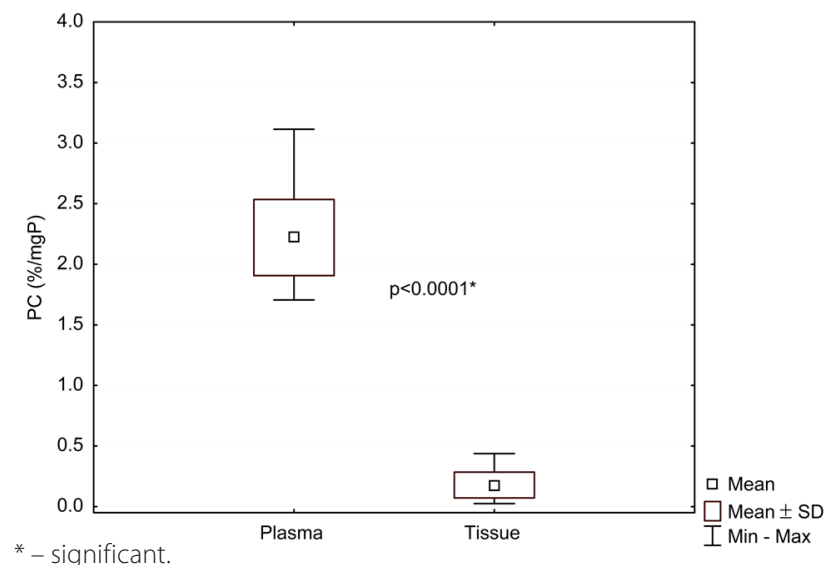


in those patients. It was 126-fold higher in the patients suffering from metastatic tumors, and 104-fold higher in patients with glioma. Thus, the TF concentration was relatively the highest in tissue homogenates derived from meningiomas, followed by metastatic tumors and the lowest in the extract derived from gliomas homogenates (Table 2).

Table 3 demonstrates the TF-Ag and TFPI-Ag concentrations and protein $\mathrm{C}$ activity in the plasma and tumor tissue homogenates in patients with intracranial tumors depending on the histological grade of the tumor malignancy, and expressed per mg of protein in the plasma and in tumor tissue homogenates. There were no significant differences depending on the histological grade of the tumor malignancy in the selected parameters.

Fig. 1 and 2 present the concentration and the activity of TFPI and protein $C$, respectively. The concentration and the activity of TFPI and protein $\mathrm{C}$ were lower in tumor tissue homogenates than in the plasma expressed per mg of protein in patients with intracranial tumors.

\section{Discussion}

This study has demonstrated a higher concentration of TF-Ag in the plasma of patients with intracranial tumors as compared to healthy individuals, which also was confirmed by the conversion of TF-Ag per mg of protein in both groups. The comparison of the concentration of TF-Ag in the plasma and in tumor tissue homogenate expressed per mg of protein indicates that the TF concentration in tumor tissue was hundreds-fold higher than in the plasma of patients with intracranial tumors.

Table 2. TF-Ag and TFPI-Ag concentrations and protein C activity in the plasma and tumor tissue homogenates in patients with intracranial tumors depending on histopathology diagnosis, and expressed per mg of protein in the plasma and in tumor tissue homogenates

\begin{tabular}{|c|c|c|c|c|c|}
\hline \multirow[b]{2}{*}{ Parameters } & \multirow[b]{2}{*}{ Statistics } & \multicolumn{3}{|c|}{ Histopathology examination } & \multirow[b]{2}{*}{$\mathrm{p}$-values } \\
\hline & & $\begin{array}{l}\text { glioma } \\
n=24\end{array}$ & $\begin{array}{c}\text { meningioma } \\
n=20\end{array}$ & $\begin{array}{c}\text { metastatic } \\
\text { tumors } \\
n=33\end{array}$ & \\
\hline $\begin{array}{l}\text { TF-Ag } \\
\text { (ng/mg P) } \\
\text { plasma }\end{array}$ & $\begin{array}{l}\text { Q1 } \\
\text { Me } \\
\text { Q3 }\end{array}$ & $\begin{array}{l}2.65 \\
4.66 \\
7.55\end{array}$ & $\begin{array}{l}2.43 \\
4.82 \\
9.73\end{array}$ & $\begin{array}{l}2.92 \\
4.60 \\
7.59\end{array}$ & 0.9810 \\
\hline $\begin{array}{l}\text { TF-Ag } \\
\text { (ng/mg P) } \\
\text { tissue }\end{array}$ & $\begin{array}{l}\text { Q1 } \\
\text { Me } \\
\text { Q3 }\end{array}$ & $\begin{array}{r}359.69 \\
486.80 \\
251709.53\end{array}$ & $\begin{array}{r}447.37 \\
756.88 \\
520050.62\end{array}$ & $\begin{array}{r}456.87 \\
582.10 \\
485373.03\end{array}$ & 0.4070 \\
\hline $\begin{array}{l}\text { TFPI-Ag } \\
\text { (ng/mgP) } \\
\text { plasma }\end{array}$ & $\begin{array}{l}\text { Q1 } \\
\text { Me } \\
\text { Q3 }\end{array}$ & $\begin{array}{l}1.25 \\
1.49 \\
1.74\end{array}$ & $\begin{array}{l}0.93 \\
1.52 \\
2.03\end{array}$ & $\begin{array}{r}1.10 \\
1.48 \\
2.64\end{array}$ & 0.7236 \\
\hline $\begin{array}{l}\text { TFPI-Ag } \\
\text { (ng/mgP) } \\
\text { tissue }\end{array}$ & $\begin{array}{l}\text { Q1 } \\
\text { Me } \\
\text { Q3 }\end{array}$ & $\begin{array}{l}0.26 \\
0.91 \\
1.27\end{array}$ & $\begin{array}{l}0.16 \\
0.34 \\
1.49\end{array}$ & $\begin{array}{l}0.35 \\
0.62 \\
1.20\end{array}$ & 0.6806 \\
\hline $\begin{array}{l}\text { Protein C } \\
(\% / m g P) \\
\text { plasma }\end{array}$ & $\begin{array}{l}M \\
S D\end{array}$ & $\begin{array}{l}2.34 \\
0.29\end{array}$ & $\begin{array}{l}1.99 \\
0.21\end{array}$ & $\begin{array}{l}2.41 \\
0.34\end{array}$ & 0.5253 \\
\hline $\begin{array}{l}\text { Protein C } \\
(\% / m g P) \\
\text { tissue }\end{array}$ & $\begin{array}{l}M \\
S D\end{array}$ & $\begin{array}{l}0.16 \\
0.13\end{array}$ & $\begin{array}{l}0.18 \\
0.08\end{array}$ & $\begin{array}{l}0.29 \\
0.16\end{array}$ & 0.3471 \\
\hline
\end{tabular}

The examination of the TF concentration in the blood of patients with various types of cancer (breast cancer, pancreatic cancer, colon cancer) demonstrates a high TF concentration, which was seen as the presence of thrombotic risk or even overt thrombosis. ${ }^{10}$ Also, patients with gliomas demonstrated high TF levels, which significantly correlated with the degree of malignancy. ${ }^{11}$ The histochemical and immunological tests of the tissue fragments derived from gliomas indicated a TF expression in tumor cells and in endothelium in new vessels created in the process of angiogenesis. ${ }^{12}$

The present study confirms that the conversion of TF concentration per mg of protein in tumor tissue homogenate and, as compared to the plasma concentration of TF expressed per mg of protein in patients with intracranial tumors, makes us aware of the huge amount of TF present in intracranial tumor cells. It is well-known that normal brain cells contain particularly high TF, similar to lung and placenta cells. This pool is further increased in cancer cells, where microRNA of tissue factor was reported. ${ }^{13}$

Our observation is extremely important in light of the study, indicating the importance of TF in processes other than coagulation activation. Numerous studies show that TF plays an important role in the stimulation of cellular responses, gene transcription, cell survival and changes in cytoskeleton, i.e., the processes required for cell functioning in the microenvironment. ${ }^{12,14}$

There are 2 known TF types: full-length TF or CD142, consisting of the extracellular, transmembrane and intracytoplasmatic parts (flTF) and, identified in 2003, alternatively spliced tissue factor (asTF). The flTF form is responsible for the activation of the coagulation process after damage to the endothelium by forming the complex with factor VII. ${ }^{15}$ The asTF form is, according to some researchers, involved in maintaining the activation of coagulation, however through factor $\mathrm{X}$ activation. ${ }^{16}$ flTF promotes the proliferation of tumor cells by the activation of PAR via flTF/VIIa complex, however asTF increases tumor cell proliferation through integrin signaling. ${ }^{15,16}$ The effect of both TF forms on tumor angiogenesis occurs through different mechanisms: flTF uses PAR2, while asTF uses integrin signaling. TF also assists the tumor cells in the metastasis of these cells, and the escape from the control of the host immune system via tumor microenvironment modulation. ${ }^{17}$

The test used in our study to measure the TF concentration in the plasma allows for identifying both TF forms, fltF and asTF. The TF source in patients with intracranial tumors is not only the endothelial cells damaged by tumor cells but also the tumor cells themselves, as seen from an extremely high TF con- 
centration in tumor tissue homogenate. It is known that intracranial tumor cells produce a number of cytokines, including VEGF-A, which strongly intensifies the permeability of vascular walls, which, in turn, can disrupt the blood-brain barrier. ${ }^{18}$ An increased TF concentration in the blood of patients with intracranial tumors may thus be associated with a disturbed function of the blood-brain barrier and the transition of TF to the blood.

Studies in recent years have shown that in patients with solid and metastatic tumors, the TF sources in blood are microparticles derived from tumor cells but also from blood cells (endothelium, platelets, leukocytes). ${ }^{19}$ Skog et al. demonstrated an increased number of microparticles in the blood of patients with gliomas, which transport RNA and protein promoting tumor growth. ${ }^{20}$ Sartori et al. showed that the microparticles circulating in the blood transport TF derived from highly malignant glioma with a potential prothrombotic effect. ${ }^{21}$

Table 3. TF-Ag and TFPI-Ag concentrations and protein C activity in the plasma and tumor tissue homogenates in patients with intracranial tumors depending on the histological grade of the tumor malignancy, and expressed per mg of protein in the plasma and in tumor tissue homogenates

\begin{tabular}{|c|c|c|c|c|}
\hline \multirow{2}{*}{ Parameter } & \multirow{2}{*}{ Statistics } & \multicolumn{2}{|c|}{$\begin{array}{l}\text { Histological grade } \\
\text { of the tumor malignancy }\end{array}$} & \multirow{2}{*}{$\mathrm{p}$-values } \\
\hline & & $\begin{array}{c}1-2 \\
n=34\end{array}$ & $\begin{array}{c}3-4 \\
n=43\end{array}$ & \\
\hline $\begin{array}{l}\text { TF } \\
\text { (ng/mL) } \\
\text { plasma }\end{array}$ & $\begin{array}{l}\text { Q1 } \\
\text { Me } \\
\text { Q3 }\end{array}$ & $\begin{array}{r}225.62 \\
331.90 \\
406.00\end{array}$ & $\begin{array}{l}168.44 \\
223.71 \\
273.41\end{array}$ & 0.1450 \\
\hline $\begin{array}{l}\text { TF } \\
\text { (ng/mg P) } \\
\text { plasma }\end{array}$ & $\begin{array}{l}\text { Q1 } \\
\text { Me } \\
\text { Q3 }\end{array}$ & $\begin{array}{l}3.78 \\
6.32 \\
7.44\end{array}$ & $\begin{array}{l}3.14 \\
4.42 \\
5.25\end{array}$ & 0.1629 \\
\hline $\begin{array}{l}\text { TF } \\
\text { (ng/mL) } \\
\text { tissue }\end{array}$ & $\begin{array}{l}\text { Q1 } \\
\text { Me } \\
\text { Q3 }\end{array}$ & $\begin{array}{r}358.00 \\
689.00 \\
391711.00\end{array}$ & $\begin{array}{r}378.00 \\
710.00 \\
421764.00\end{array}$ & 0.3685 \\
\hline $\begin{array}{l}\text { TF } \\
\text { (ng/mg P) } \\
\text { tissue }\end{array}$ & $\begin{array}{l}\text { Q1 } \\
\text { Me } \\
\text { Q3 }\end{array}$ & $\begin{array}{r}316.73 \\
494.83 \\
362766.21\end{array}$ & $\begin{array}{r}326.16 \\
547.70 \\
386511.26\end{array}$ & 0.7330 \\
\hline $\begin{array}{l}\text { TFPI } \\
\text { (ng/mL) } \\
\text { plasma }\end{array}$ & $\begin{array}{l}\text { Q1 } \\
\text { Me } \\
\text { Q3 }\end{array}$ & $\begin{array}{r}75.96 \\
83.02 \\
101.08\end{array}$ & $\begin{array}{r}91.88 \\
115.40 \\
133.44\end{array}$ & 0.0586 \\
\hline $\begin{array}{l}\text { TFPI } \\
\text { (ng/mg P) } \\
\text { plasma }\end{array}$ & $\begin{array}{l}\text { Q1 } \\
\text { Me } \\
\text { Q3 }\end{array}$ & $\begin{array}{l}1.27 \\
1.50 \\
1.70\end{array}$ & $\begin{array}{l}1.48 \\
2.03 \\
2.64\end{array}$ & 0.1138 \\
\hline $\begin{array}{l}\text { TFPI } \\
\text { (ng/mL) } \\
\text { tissue }\end{array}$ & $\begin{array}{l}\text { Q1 } \\
\text { Me } \\
\text { Q3 }\end{array}$ & $\begin{array}{l}1.78 \\
3.96 \\
4.83\end{array}$ & $\begin{array}{r}3.26 \\
8.17 \\
12.16\end{array}$ & 0.2778 \\
\hline $\begin{array}{l}\text { TFPI } \\
\text { (ng/mg P) } \\
\text { tissue }\end{array}$ & $\begin{array}{l}\text { Q1 } \\
\text { Me } \\
\text { Q3 }\end{array}$ & $\begin{array}{l}0.14 \\
0.32 \\
0.95\end{array}$ & $\begin{array}{l}0.34 \\
0.62 \\
0.94\end{array}$ & 0.4025 \\
\hline $\begin{array}{l}\mathrm{PC}(\%) \\
\text { plasma }\end{array}$ & $\begin{array}{l}M \\
S D\end{array}$ & $\begin{array}{r}115.80 \\
11.10\end{array}$ & $\begin{array}{r}123.20 \\
7.35\end{array}$ & 0.0682 \\
\hline $\begin{array}{l}\mathrm{PC}(\% / \mathrm{mg} P) \\
\text { plasma }\end{array}$ & $\begin{array}{l}M \\
S D\end{array}$ & $\begin{array}{l}2.12 \\
0.23\end{array}$ & $\begin{array}{l}2.30 \\
0.35\end{array}$ & 0.1733 \\
\hline $\begin{array}{l}\text { PC (\%) } \\
\text { tissue }\end{array}$ & $\begin{array}{l}M \\
S D\end{array}$ & $\begin{array}{l}1.62 \\
1.09\end{array}$ & $\begin{array}{l}1.93 \\
1.29\end{array}$ & 0.5491 \\
\hline $\begin{array}{l}\mathrm{PC}(\% / \mathrm{mg} P) \\
\text { tissue }\end{array}$ & $\begin{array}{l}M \\
S D\end{array}$ & $\begin{array}{l}0.15 \\
0.08\end{array}$ & $\begin{array}{r}0.20 \\
0.12\end{array}$ & 0.2670 \\
\hline
\end{tabular}

In the blood of patients with intracranial tumors we have recorded an elevated TFPI concentration and increased protein $C$ activity. TFPI and protein $C$ are connected with the endothelium surface, and their increased presence in the blood of intracranial tumor patients is an expression of the compensatory response of the body to the elevated TF concentration in the patient's blood.

The analysis of the available literature shows that an increased concentration and activity of protein $C$ was reported in patients with nephrotic syndrome and in patients suffering from alcoholic and non-alcoholic cirrhosis. ${ }^{22,23}$ Agewall et al. suggested that increased protein $\mathrm{C}$ concentration depends on intensified protein $\mathrm{C}$ synthesis by the liver. ${ }^{24} \mathrm{~A}$ high protein $\mathrm{C}$ concentration was also observed in patients with stroke and such a high level persisted for the following 2 months. ${ }^{25}$ According to the authors, a high concentration of protein can be an independent positive predicting factor in patients with acute stroke.

The present observation of high protein $\mathrm{C}$ activity, along with a high TF concentration, in the blood of patients suffering from intracranial tumors becomes especially important in conjunction with the research performed over the recent years demonstrating the pleiotropic properties of protein $C$. It has been shown that active protein $C$ inhibits apoptosis by stimulating anti-apoptotic Bcl-2 and inhibiting proteins p53 and Bax with a proapoptotic effect. Protein $C$ is also capable of inhibiting the migration of immunological cells. These effects of protein $C$ are intensified once it connects with receptor EPCR found on the endothelium cell surface. It has also been demonstrated that protein $\mathrm{C}$ stimulates angiogenesis via the endothelial nitric oxide synthase (eNOS) pathway. Protein $C$ increases the proliferation and migration of keratinocytes by intensifying the expression and activation of extracellular matrix metalloproteinase MMP-2. ${ }^{26,27}$

Unlike in blood tests in intracranial tumor patients, protein $\mathrm{C}$ activity in tumor tissue homogenate was significantly lower. The clinical study analysis demonstrates that a decrease in the concentration and activity of protein $\mathrm{C}$ is essential in congenital and acquired thrombophilia. Congenital thrombophilia depends on a genetically-conditioned protein $\mathrm{C}$ deficiency or the presence of inactive protein. Acquired thrombophilia, however, depends on the consumption of protein $C$ in the coagulation process in the case of the occurrence of the thrombotic process in the patient. It seems that a decrease in the activity of protein $\mathrm{C}$ in tumor tissue homogenates is due to the vast presence of TF in brain cells and its additional production by tumor cells. ${ }^{28}$

In the blood of intracranial tumor patients, we have noted an increase in the TFPI concentration, as compared to healthy individuals. The applicable literature shows that an increased TFPI concentration in the blood occurs in ischemic heart disease, in patients with diabetes type 1 and 2 . An elevated concentration of the whole TFPI pool was reported in patients 
with solid tumors (lung, colon, breast and pancreas cancer), Hodgkin's and non-Hodgkin lymphomas. ${ }^{22}$ It is claimed that an increase in TFPI is a result of its mobilization from the vessel wall since its major source are the endothelium cells derived from microcirculation. In patients with intracranial tumors, endothelium can also be the source of TFPI, and the factor which cause TFPI release into the blood seems to be cytokines produced by tumor cells.

In the case of a high TFPI concentration in the blood, one should stress that the major TF-dependent coagulation pathway inhibitor has also other properties; it has been demonstrated that TFPI is capable of inhibiting the transmission of signals triggered by complex TF/ VIIa. ${ }^{29}$

However, in intracranial tumor homogenates, a lowered TFPI concentration was noted. The literature analysis demonstrates that a lowered concentration of that inhibitor occurs in the active thrombotic process, in patients with a cerebro-vascular accident, as well as in patients undergoing serious operative procedures. ${ }^{30}$ In all cases, the lowered concentration is a result of TFPI consumption in the thrombotic process. One should note that in homogenates derived from intracranial tumors, a low concentration of that inhibitor of TF-dependent activation is connected with a considerable amount of tissue factor.

A limitation of this paper is the low number of patients qualified for the study. The results must be considered preliminary. The study is still in progress and new patients are successively included to the study group.

\section{Conclusions}

The study confirmed the essential prothrombotic blood properties in patients with intracranial tumors, expressed with an elevated TF level as well as a tremendous amount of TF in tumor tissue homogenate derived from tumors. An elevated concentration of TFPI and protein $C$ activity in the blood converted per mg of total protein should be analyzed in terms of their pleiotropic function, along with the participation in hemostasis control. It seems that the reduced protein $\mathrm{C}$ activity and low TFPI level are associated with the enormous TF value in tumor tissue homogenates.

\section{References}

1. Chu AJ. Tissue factor, blood coagulation, and beyond: An overview. Int J Inflam. 2011;2011:367284.

2. Tang H, Fang J, Shu K, et al. Tissue factor/ FVII regulates doxorubicin-induced apoptosis in glioblastoma via activating PI3K/Akt signaling. Chinese-German J Clin Oncol. 2007;6:487-491.

3. Magnus N, Meehan B, Garnier D, et al. The contribution of tumor and host tissue factor expression to oncogene-driven gliomagenesis. Bioch Biophys Res Communic. 2014;454:262-268.

4. Wood JP, Ellery PE, Maroney SA, Mast AE. Biology of tissue factor pathway inhibitor. Blood. 2014;123:2934-2943.

5. Opstad TB, Pettersen AA, Weiss T, Arnesen H, Seljeflot I. Gender differences of polymorphisms in the TF and TFPI genes, as related to phenotypes in patients with coronary heart disease and type-2 diabetes. Thromb J. 2010;8:7.

6. Owens AP III, Mackman N. Tissue factor and thrombosis: The clot starts here. Thromb Haemost. 2010;104:432-439.

7. Bouwens EA, Stavenuiter F, Mosnier LO. Mechanisms of anticoagulant and cytoprotective actions of the protein C pathway. J Thromb Haemost. 2013;11:242-253.

8. Griffin JH, Zlokovic BV, Mosnier LO. Protein C anticoagulant and cytoprotective pathways. Int J Hematol. 2012;95:333-345.

9. Gabre J, Chabasse C, Cao C, et al. Activated protein C accelerates venous thrombus resolution through heme oxygenase-1 induction. J Thromb Haemost. 2014;12:93-102.

10. Cole $M$, Bromberg $M$. Tissue factor as a novel target for treatment of breast cancer. Oncologist. 2013;18:14-18.

11. Perry JR. Thromboembolic disease in patients with high-grade glioma. Neuro Oncol. 2012;14:73-80.

12. Magnus N, Garnier D, Meehan B, et al. Tissue factor expression provokes escape from tumor dormancy and leads to genomic alterations. Proc Natl Acad Sci USA. 2014;111:3544-3549.

13. Monteiro RQ, Lima LG, Gonçalves NP, et al. Hypoxia regulates the expression of tissue factor pathway signaling elements in a rat glioma model. Oncol Lett. 2016;12:315-322.

14. Butenas S. Tissue factor structure and function. Stientifica. 2012;2012:964862.

15. Han X, Guo B, Li Y, Zhu B. Tissue factor in tumor microenvironment: A systematic review. J Hematol Oncol. 2014;7:54.

16. Ruf W, Disse J, Carneiro-Lobo TC, Yokota N, Schaffner F. Tissue factor and cell signalling in cancer progression and thrombosis. J Thromb Haemost. 2011;9:306-315.

17. van den Berg YW, Osanto S, Reitsma PH, Versteeg $\mathrm{HH}$. The relationship between tissue factor and cancer progression: Insights from bench and bedside. Blood. 2012;119:924-932.

18. Cai Y, Wu J, Li Z, Long Q. Mathematical modelling of a brain tumour initiation and early development: A coupled model of glioblastoma growth, pre-existing vessel co-option, angiogenesis and blood perfusion. PLoS One. 2016;11:e0150296.

19. Rak J. Micropaticles in cancer. Semin Thromb Haemost. 2010;36(8):888-906.

20. Skog J, Würdinger T, van Rijn $S$, et al. Glioblastoma microvesicles transport RNA and proteins that promote tumour growth and provide diagnostic biomarkers. Nat Cell Biol. 2008;10:1470-1476.

21. Sartori MT, Della Puppa A, Ballin A, et al. Circulating microparticles of glial origin and tissue factor bearing in high-grade glioma: A potential prothrombotic role. Thromb Haemost. 2013;110:378-385.

22. Iversen N, Lindahl AK, AbildgaardU. Elevated plasma levels of the factor Xa-TFPI complex in cancer patients. Thromb Res. 2002;105:33-36.

23. Assy N, Schlesinger $\mathrm{S}$, Hussein O. Elevated plasma protein $\mathrm{C}$ levels correlate with the presence of fatty liver (NASH and NAFLD). GUT. 2005;54:729.

24. Agewall S, Bokemark L, Wikstrand J, Lindahl A, Fagerberg B. Insulin sensitivity and haemostatic factors in clinically healthy 58-year old men. Throm Haemost. 2000;84:571-575.

25. D'Angelo A, Landi G, Vigano'D'Angelo $S$, et al. Protein $C$ in acute stroke. Stroke. 1988;19:579-583.

26. Beaulieu LM, Church FC. Activated protein C promotes breast cancer cell migration through interactions with EPCR and PAR-1. Exp Cell Res. 2007;313:677-687.

27. Schaffner F, Yokota N, Carneiro-Lobo T, et al. Endothelial protein $C$ receptor function in murine and human breast cancer development. Plos One. 2013;8(4):e61071.

28. Minuk L, Lazo-Langner A, Kovacs J, Robbins M, Morrow B, Kovacs M. Normal levels of protein $C$ and protein $S$ tested in the acute phase of a venous thromboembolic event are not falsely elevated. Thromb J. 2010;8:1-4.

29. Ahamed J, Belting M, Ruf W. Regulation of tissue factor-induced signaling by endogenous and recombinant tissue factor pathway inhibitor 1. Blood. 2005;105:2384-2391.

30. Amirkhosravi A, Meyer T, Amaya $M$, et al. The role of tissue factor pathway inhibitor in tumor growth and metastasis. Sem Throm Haemost. 2007;33:643-652. 